\title{
Metabolic Activity of Developing Rabbit Lung
}

\author{
MARGIT HAMOSH, ${ }^{(37)}$ YAEL SHECHTER, AND PAUL HAMOSH \\ Department of Physiology and Biophysics, Georgetown University Medical School, Washington, DC, USA
}

\begin{abstract}
Summary
The uptake and metabolism of $\left[{ }^{3} \mathrm{H}\right]$ leucine, $\left[U-{ }^{14} \mathrm{C}\right]$ glucose, and $\left[{ }^{3} \mathrm{H}\right]$ palmitate were studied in rabbits aged $-3,1,7,28$, and 90 days up to 1-1.5 years. Although lung composition did not change markedly, there were great differences in lung metabolism between the perinatal period (late fetal and newborn) and later stages of development.

Leucine incorporation into lung protein was highest (3.1-3.4 $\mathrm{nmol} / \mathrm{mg}$ protein/hr) in late fetal and newborn rabbits and decreased rapidly thereafter. Palmitic acid incorporation decreased during the first week after birth from $150 \mathrm{nmol} / 100$ $\mathrm{mg} / \mathrm{hr}$ to $85 \mathrm{nmol} / 100 \mathrm{mg} / \mathrm{hr}$ at 7 days of age; it increased thereafter to $170 \mathrm{nmol} / 100 \mathrm{mg} / \mathrm{hr}$ at 4 weeks of age and remained at that level throughout the entire period studied. Glucose uptake and lactate production were higher in fetal lungs than in all other age groups. Lipid biosynthesis from glucose was 2-4 times higher in fetal lungs than at all other ages; furthermore, more than $60 \%$ of glucose carbon atoms channeled into lipid was incorporated into fatty acids, whereas at all other ages glucose was chiefly a precursor of lipid glycerol.
\end{abstract}

\section{Speculation}

Our data suggest that late fetal lung has a high metabolic activity that corresponds to the high synthetic demands of a rapidly growing and differentiating organ. Our study shows a higher glucose uptake in fetal and newborn lung than at later ages. Of special significance is the finding that lipid and, especially, fatty acid synthesis from glucose, is highest in the fetal lung. Since glucose is incorporated chiefly into phospholipids, the 7-8 times higher incorporation of glucose carbons into phospholipid fatty acid could have special significance for surfactant biosynthesis.

Surfactant production is closely linked to lung maturation and is of prime importance to the ability of the premature or term infant to survive $(9,13)$. It is for this reason that most of the interest in lung metabolism during the perinatal period has been focused on surfactant synthesis and secretion $(13,14,20$, 28 ). With the exception of collagen (3) and glycosaminoglycan synthesis (18), very little is known on other aspects of lung metabolism during this period of rapid lung growth; in addition, there are only few systematic studies that extend throughout the developmental period into adulthood and old age. In the present study, we have investigated glucose metabolism and lipid and protein synthesis in rabbit lung from 3 days before birth to 2 years of age.

\section{MATERIALS AND METHODS}

\section{ANIMALS}

New Zealand white rabbits were obtained from the $\mathrm{B}$ and $\mathrm{H}$ Rabbitry, Rockville, MD. Newborn rabbits up to 3 weeks of age were on a diet of mother's milk only; between 3 and 8 weeks they were on a mixed diet of milk and solid food, and after 8 weeks they received only solid food (nonmedicated Purina rabbit chow). Old rabbits were breeding females 1-1.5 years old. The animals were anesthetized with sodium Nembutal (Abbott Laboratories, Chicago, IL), $50 \mathrm{mg} / \mathrm{kg}$ iv for rabbits 3 months and older, or $25-50 \mathrm{mg} / 100 \mathrm{~g}$ ip for the younger rabbits. The lungs were cannulated, removed, and lavaged with a sterile solution of Krebs-Ringer-bicarbonate (31) buffer containing $0.2 \%$ glucose for the harvest of alveolar macrophages (34). The lungs were then kept in petri dishes in ice for 15-45 min until incubation. Lung slices $1 \mathrm{~mm}$ thick (22) were prepared with a McIlwain tissue slicer (Brinkman Instruments, Westbury, NY). Tissue slices (50-80 mg) were incubated in $2 \mathrm{ml}$ KrebsRinger bicarbonate buffer for the study of lung metabolism as described below.

\section{MATERIALS}

All chemicals used were of the highest purity obtainable commercially. Radioactive chemicals (D- $\left[U-{ }^{14} \mathrm{C}\right]$ glucose, L[4,5- $\left.{ }^{3} \mathrm{H}\right]$ leucine, and $\left[9,10^{-3} \mathrm{H}\right]$ palmitic acid) were purchased from New England Nuclear, Boston, MA.

\section{GLUCOSE METABOLISM}

Tissue slices were incubated in $2 \mathrm{ml} \mathrm{Krebs-Ringer} \mathrm{bicarbonate}$ buffer containing $75 \mathrm{mg} / 100 \mathrm{ml}$ carrier and $0.3 \mu \mathrm{Ci} / \mathrm{ml} \mathrm{D}-[U$ ${ }^{14} \mathrm{C}$ ]glucose. The incubation flasks were capped with serum stoppers equipped with plastic disposable $\mathrm{CO}_{2}$ collection vials (Kontes Company, Vineland, $\mathrm{NJ})$ containing fluted $(4 \times 2.5$ $\mathrm{cm})$ Whatman no. 1 filter paper. The flasks were aerated for 1 min with $95 \% \mathrm{O}_{2}-5 \% \mathrm{CO}_{2}$; incubation was for $15-180 \mathrm{~min}$ at $37^{\circ}$ in a Dubnoff shaking bath. The reaction was stopped by the injection of $0.2 \mathrm{ml} 30 \%$ perchloric acid into the medium; 0.2 ml phenethylamine (Scintanalyzed, Fisher Scientific Company, Fairlawn, NJ) was injected into the filter paper in the center well and the flasks were kept at room temperature for an additional $30 \mathrm{~min}$ for the collection of ${ }^{14} \mathrm{CO}_{2}$. The filter papers were then transferred to counting vials containing $10 \mathrm{ml} 4.2 \%$ RPI PPO-POPOP scintillator in toluene (RPI Research Products International Corporation, Elk Grove Village, IL). The incubation medium was stored at $-18^{\circ}$ for the determination of glucose (15) and lactate (17). The tissues were rinsed in saline and homogenized in chloroform-methanol $(2: 1)$ and the lipids were extracted and washed according to the method of Folch $e t$ al. (11). An aliquot of the lipids was saponified $\left(1 \mathrm{hr}\right.$ at $60^{\circ}$ in 1 $\mathrm{ml}$ saturated aqueous $\mathrm{KOH}$-ethanol, 1:20) and the radioactivity present in tissue total lipid, fatty acids, and glyceride-glycerol was measured by liquid scintillation spectrometry.

\section{PALMITATE METABOLISM}

Tissue slices $(50-80 \mathrm{mg}$ ) were incubated in $2 \mathrm{ml}$ KrebsRinger bicarbonate buffer (slightly modified to contain only $25 \%$ of the regular $\mathrm{Ca}^{++}$concentration) containing $2 \%$ bovine serum albumin (Fraction V, Armour Pharmaceutical Company, Kanakee, IL, lot N-50402), $10 \mathrm{mg} / 100 \mathrm{ml}$ glucose, and 0.05 $\mu \mathrm{Ci} / 1.5 \mu \mathrm{mol} / \mathrm{ml} 9-10$ [' $\mathrm{H}$ ]palmitic acid. Albumin-bound palmitic acid was prepared according to the method of Darrah and 
Hedley-Whyte (8). Incubation was at $37^{\circ}$ for $15-180 \mathrm{~min}$. At the end of the incubation the tissues were carefully rinsed in $1 \%$ albumin solution to remove adsorbed palmitic acid, and then homogenized in chloroform-methanol $(2: 1)$; lipids were extracted and washed according to the method of Folch et al. (11). Free palmitic acid was separated from esterified palmitate by a modification (16) of the method of Borgstrom (2). Phospholipids and neutral lipids in the chloroform extract were separated by thin layer chromatography on silica gel sheets (Eastman Kodak Co. Rochester, NY). The solvent system for phospholipid separation was chloroform-methanol-water (70:30:3.5) (8); neutral lipids were separated with a solvent system containing petroleum ether $\left(30-60^{\circ} \mathrm{bp}\right)$ ethyl ether-glacial acetic acid (120:46.6:1) (16). Reference standards were obtained from Applied Chemicals Co., University Park, PA. The spots were localized by a brief exposure to iodine vapor, cut out, and transferred to scintillation vials containing $10 \mathrm{ml}$ $4.2 \%$ RPI scintillator.

\section{LEUCINE INCORPORATION INTO PROTEIN}

Lung slices were incubated in $2 \mathrm{ml}$ Krebs-Ringer bicarbonate buffer containing $0.5 \mu \mathrm{Ci} \mathrm{L-}\left[4,5-{ }^{3} \mathrm{H}\right]$-leucine and $0.2 \mu \mathrm{mol}$ carrier L-leucine $/ \mathrm{ml}$. Glucose was present at a concentration of $75 \mathrm{mg} / 100$. Incubation was at $37^{\circ}$ for $15-180 \mathrm{~min}$. At the end of the incubation the tissue was rinsed with saline and homogenized. To precipitate the proteins, 1 vol $100 \%$ cold trichloroacetic acid (TCA) was added to 9 vol homogenate (final TCA concentration was $10 \%$ ). The mixtures were kept overnight at $4^{\circ}$ and were then centrifuged, the supernatant was decanted and the TCA precipitate was washed twice with $10 \%$ cold TCA. Lipids were extracted (24) with $2 \mathrm{ml}$ ethyl ether-acetonechloroform $(2: 2: 1, \mathrm{v} / \mathrm{v})$ at $60^{\circ}$ for $30 \mathrm{~min}$. The organic solvents were removed and the precipitates were air-dried and solublized in $5 \mathrm{ml} \mathrm{I} \mathrm{N} \mathrm{NaOH}$ by heating at $80^{\circ}$ for $30 \mathrm{~min}$. Aliquots $(0.1-$ $0.2 \mathrm{ml}$ ) were taken for liquid scintillation spectrometry and for protein determination (23).

Incubation flasks in all experiments (with the exception of glucose incorporation) were aerated throughout incubation with $95 \% \mathrm{O}_{2}-5 \% \mathrm{CO}_{2}$. Wet weight of lung slices was determined at the end of the incubation after eliminating excess moisture with gentle suction on a Buchner funnel. Control flasks containing lung slices and incubation medium were prepared for each experiment and were incubated in crushed ice for 60-180 min. Radioactivity in all samples was measured by liquid scintillation spectrometry in a Mark II liquid scintillation spectrometer, (Searle Radigraphics, Inc. Des Plaines, IL).

Aqueous samples were counted in $10 \mathrm{ml}$ scintillation fluid consisting of $24 \%$ Triton X-100 (New England Nuclear, Pilot Chemicals Division, Boston, MA, catalog no. NEF-936) and $5 \%$ RPI PPO-POPOP scintillator in toluene; when needed, water (up to $0.5 \mathrm{ml}$ ) was added to the counting vials to clear the mixture. Counting efficiency was $90-95 \%$ for ${ }^{14} \mathrm{C}$ and $50-$ $55 \%$ for ${ }^{3} \mathrm{H}$. Appropriate internal standards were used to determine corrections for quench.

\section{TISSUE ANALYSIS}

Dry weight was determined on 300- to $400-\mathrm{mg}$ lung samples; the tissues were kept at $80^{\circ}$ until constant weight was reached (1-3 days). Tissue samples for DNA, RNA, and protein analysis were rapidly frozen and kept at $-70^{\circ}$ until analysis. DNA was determined with the diphenylamine reagent $(4,29)$ using calf thymus (Sigma Chemical Co. St. Louis, MO, lot 93C-9501-95) as references standard. RNA was measured with orcinol reagent (29) using yeast RNA (Sigma, type X1, lot 24C-8150) as standard. Protein was measured by the method of Lowry (23) using crystalline bovine serum albumin (Sigma, lot 83C-8090) as standard.

\section{LIPID ANALYSIS}

Tissue (250-300 mg) was weighed rapidly and homogenized in chloroform-methanol $(2: 1)$. Samples were stored at $-18^{\circ}$ under nitrogen until further analysis. The chloroform layer was separated and washed by the method of Folch $e t$ al. (11). The phospholipids were separated from neutral lipids by column chromatography on silicic acid (Unisil, 100-200 mesh, Clarkson Chemical Co., Williamsport PA). The silicic acid was activated at $100^{\circ}$ for $30 \mathrm{~min}$, dispersed in methanol, poured in columns (Plastic disposable columns no. 3030-31, Evergreen Scientific, Los Angeles, CA), and washed with $20 \mathrm{vol}$ methanol followed by 20 vol chloroform. Chloroform $(0.3-0.5 \mathrm{ml})$ containing the lipid to be analyzed (2-4 mg total lipid) was applied and eluted from the column with $10 \mathrm{ml}$ chloroform (Fraction 1), $5 \mathrm{ml} 5 \%$ $\mathrm{v} / \mathrm{v}$ methanol in chloroform (Fraction 2), $5 \mathrm{ml} 40 \% \mathrm{v} / \mathrm{v}$ methanol in chloroform (Fraction 3), and $5 \mathrm{ml}$ methanol (Fraction 4). The lipid composition of the four fractions was checked by thin layer chromatography on silica gel plates as described above. Neutral lipids were recovered $(95-98 \%)$ in Fraction 1. Fraction 2 contained traces of neutral lipid (monoglyceride and diglycer-

Table 1. Measurements in growing rabbits ${ }^{1}$

\begin{tabular}{lcccc}
\hline \multicolumn{1}{c}{ Age } & No. of animals & Body wt, $\mathrm{g}$ & Lung wt, $\mathrm{g}$ & Lung wt, g/100 g body wt \\
\hline Fetal (28 days) & 12 & $29.2 \pm 1.48$ & $0.80 \pm 0.06$ & $2.75 \pm 0.25$ \\
30 days & 8 & $43.6 \pm 2.4$ & $0.95 \pm 0.05$ & $2.17 \pm 0.11$ \\
$5-7$ hr after birth & 19 & $54.4 \pm 1.4$ & $0.83 \pm 0.03$ & $1.52 \pm 0.09$ \\
1 day & 10 & $68.7 \pm 2.3$ & $0.97 \pm 0.07$ & $1.41 \pm 0.08$ \\
7 days & 15 & $104.3 \pm 3.7$ & $1.25 \pm 0.06$ & $1.20 \pm 0.06$ \\
30 days & 11 & $534 \pm 29.6$ & $3.7 \pm 0.24$ & $0.69 \pm 0.04$ \\
9 days & 6 & $2,700 \pm 1.50$ & $10.0 \pm 0.54$ & $0.37 \pm 0.02$ \\
\hline
\end{tabular}

1 Results are mean \pm SE. Gestation in the rabbit is 31 days; the animals are mature at 90 days. There were several litters in age groups fetal to 30 days; there were three to four rabbits per litter.

Table 2. Composition of developing rabbit lungs

\begin{tabular}{lccccc}
\hline \multicolumn{1}{c}{ Age } & $\begin{array}{c}\text { No. of ani- } \\
\text { mals }\end{array}$ & Dry wt, \% of wet wt & Protein, \% & DNA, $\mu \mathrm{g} / \mathrm{mg}$ protein & RNA, $\mu \mathrm{g} / \mathrm{mg}$ protein \\
\hline Fetal (28 days) & 13 & $11.4 \pm 0.60$ & $9.2 \pm 0.45$ & $52.2 \pm 8.0$ & $71.9 \pm 10.0$ \\
1 day & 14 & $11.2 \pm 0.25$ & $9.3 \pm 0.40$ & $50.1 \pm 5.0$ & $69.7 \pm 6.0$ \\
7 days & 18 & $11.4 \pm 0.9$ & $9.3 \pm 0.30$ & $57.4 \pm 7.4$ & $73.8 \pm 15.0$ \\
30 days & 6 & $11.5 \pm 0.7$ & $9.5 \pm 0.60$ & $40.5 \pm 2.5$ & $62.0 \pm 12.0$ \\
90 days & 6 & $13.2 \pm 0.5$ & $9.7 \pm 0.85$ & $48.6 \pm 5.0$ & $70.5 \pm 10.0$ \\
$1.2-1.8$ years & 4 & $14.2 \pm 0.8$ & $10.3 \pm 1.0$ & $39.3 \pm 4.8$ & $57.0 \pm 7.0$ \\
\hline
\end{tabular}

\footnotetext{
${ }^{1}$ Results are mean $\pm \mathrm{SE}$.
} 
Table 3. Lipid composition of developing rabbit lungs ${ }^{1}$

\begin{tabular}{lcccc}
\hline \multicolumn{1}{c}{ Age } & Total lipid, $\mathrm{mg} / \mathrm{g}$ & Phospholipid, $\mu$ mol/g & Phosphatidyl choline ${ }^{2}$ & $\begin{array}{c}\text { Neutral lipid, } \mu \text { Eq FA es- } \\
\text { ter/g }\end{array}$ \\
\hline Fetal (28 days) & $13.66 \pm 1.8$ & $15.50 \pm 0.77$ & $54.3 \pm 3.5$ & $8.16 \pm 1.11$ \\
1 day & $14.40 \pm 1.3$ & $16.26 \pm 1.25$ & $53.9 \pm 3.8$ & $8.50 \pm 1.20$ \\
7 days & $14.98 \pm 0.90$ & $17.03 \pm 1.46$ & $53.8 \pm 1.6$ & $8.84 \pm 1.13$ \\
30 days & $16.50 \pm 1.87$ & $20.0 \pm 2.49$ & $57.2 \pm 1.75$ & $6.60 \pm 0.30$ \\
90 days & $16.4 \pm 0.90$ & $21.13 \pm 1.20$ & $58.3 \pm 1.5$ & $7.16 \pm 0.43$ \\
$1.2-1.8$ years & $18.94 \pm 1.42$ & $22.39 \pm 2.60$ & $54.8 \pm 1.55$ & $7.95 \pm 1.14$ \\
\hline
\end{tabular}

1 All results are expressed per $\mathrm{g}$ wet weight. FA: fatty acid. Data are mean \pm SE. There were 6-12 animals in each group. Lipids were separated by silicic acid column chromatography. Phospholipids were quantitated by phosphorus determination (1); glyceride ester bond was measured by the hydroxamic acid method (27). For details see Methods.

${ }^{2}$ Percentage of total phospholipid.

Table 4. Effect of lavage on lung metabolism'

\begin{tabular}{ccc}
\hline \multicolumn{1}{c}{ Experiment } & Lavaged lung & Nonlavaged lung \\
\hline $\begin{array}{c}\text { Glucose metabolism } \\
\text { Lipid synthesis, } \mu \mathrm{mol} /\end{array}$ & $0.042 \pm 0.005$ & $0.046 \pm 0.003$ \\
$\quad 100 \mathrm{mg} / \mathrm{hr}$ & $18.4 \pm 2.7$ & $17.2 \pm 2.0$ \\
$\mathrm{CO}_{2}$ production, $\%$ & $0.17 \pm 0.02$ & $0.16 \pm 0.022$ \\
$\begin{array}{c}\text { Palmitate uptake } \mu \mathrm{mol} / \\
\quad 100 \mathrm{mg} / \mathrm{hr}\end{array}$ & $0.97 \pm 0.08$ & $1.04 \pm 0.09$ \\
$\begin{array}{c}\text { Leucine incorporation } \\
\mathrm{nmol} / \mathrm{mg} \text { protein/hr }\end{array}$ & & \\
\hline
\end{tabular}

1 Results are mean \pm SE of three experiments. Adult rabbits were anesthetized, the lungs were removed, and one lung was lavaged. The contralateral lung was the nonlavaged control. The experiments were repeated with rabbits of various ages with the same results, i.e., there was no difference in the incorporation of labeled precursors by lavaged or nonlavaged lungs.

ide) and traces of phospholipid (not more than $5 \%$ of total phospholipids). Fraction 3 contained mostly phosphatidylethanolamine and small amounts of phosphatidylcholine, and Fraction 4 contained phosphatidylcholine (about $85-90 \%$ of the total amount) lysolecithin and sphingomyelin. Neutral lipids were quantitated by the hydroxamic acid method (27) and phospholipids by measuring the organic phosphorus content (1).

\section{RESULTS}

The relationship of lung weight to body weight in late fetal, newborn, and developing rabbits is shown in Table 1 . Lung weight, expressed as percentage of body weight, decreased rapidly from $2.7 \% 3$ days before birth to $2.1 \% 1$ day before birth and $1.5 \%$ several hours after birth. The lungs reached the adult level of $0.4 \%$ of body weight at the age of 3 months.

\section{COMPOSITION OF RABBIT LUNG}

The composition of rabbit lung from 28 days in utero throughout development and up to $\mathbf{1 . 8}$ years of age is shown in Table 2. Lung dry weight and protein content were unchanged from -3 days to 30 days of age (mean values were $11.4 \%$ and $9.3 \%$, respectively); there was a $15-23 \%$ increase in dry weight at 90 days and 1.2-1.8 years; protein concentration was unchanged during the first month after birth and increased only $10 \%$ from 30 days of age to 1.8 years. DNA concentration $(\mu \mathrm{g} / \mathrm{mg}$ protein) decreased after 30 days of age from a level of $50.2-57.4 \mu \mathrm{g} / \mathrm{mg}$ protein during the first week after birth to an average of $40 \mu \mathrm{g} /$ mg protein between 1 month and 1.8 years. There were only small fluctuations in the RNA level between -3 days and 90 days; however, at 1.8 years of age the RNA level was $20 \%$ lower. The lipid composition of rabbit lung is shown in Table 3. The composition of total lipids and phospholipids changed only slightly from 3 days before birth to 7 days after birth. Although there were no marked changes in the lipid composition, there was a gradual rise $(40-50 \%)$ in phospholipid and total lipid content, respectively, from 1 day after birth to 1.8 years of age. Phosphatidylcholine made up 50-60\% of lung phospholipids.

Since at all ages tested (except in fetal rabbits) the lungs were lavaged prior to the preparation of slices, we tested whether this procedure affects lung metabolism. As shown in Table 4, lung metabolism was unaffected by lavage.

\section{INCORPORATION OF [ $\left.{ }^{3} \mathrm{H}\right]$ LEUCINE INTO LUNG PROTEIN (FIG. 1)}

Incorporation of leucine into acid-insoluble material was high. est in the perinantal period ( 3 days before birth and 1 day after birth). Leucine incorporation decreased from $3.34 \pm 0.30 \mathrm{nmol} /$ $\mathrm{mg}$ protein $/ \mathrm{hr}$ to $2.30 \mathrm{nmol} / \mathrm{mg}$ protein per hr at 7 days of age; a further slight decrease occurred between 4 weeks and 3 months of age ( 2.4 and $1.66 \mathrm{nmol} / \mathrm{mg}$ protein/hr, respectively). Leucine incorporation into protein was linear during an incubation of 3 $\mathrm{hr}$ in all age groups studied (Fig. 2). The marked decrease in leucine incorporation with increasing age is again apparent. Addition of cycloheximide $\left(5 \times 10^{-4} \mathrm{M}\right)$ to the incubation medium caused a $90-95 \%$ inhibition of leucine incorporation into protein in all ages studied.

Glucose uptake was higher in fetal rabbits than in all other age groups (Table 5). Lactate production was higher in fetal and 1 day-old rabbits than at all other ages, $76 \%$ and $71 \%$ of the glucose taken up was metabolized to lactate in fetal and 1-day-old rabbits as compared to $52-45 \%$ in the older age groups. Of the glucose taken up by the lung, $6.6 \%$ was channeled into lipid synthesis in fetal lungs as compared to only $2-3 \%$ in the other age groups. Furthermore, incorporation of glucose carbon into the fatty acid moiety of lung lipids was 4 times higher in fetal lungs than in lungs of 7-day to 1.5 -year-old rabbits. Of the glucose carbon incorporated into lipid, $75-80 \%$ was found in lung phospholipids at all ages studied. There were no differences in $\mathrm{CO}_{2}$ production between the various age groups.

Palmitic acid incorporation (Fig. 3) decreased during the first week after birth from $150 \mathrm{nmol} / 100 \mathrm{mg} / \mathrm{hr}$ to $85 \mathrm{nmol} / 100 \mathrm{mg} /$ hr at 7 days of age; it increased thereafter to $170 \mathrm{nmol} / 100 \mathrm{mg} /$ hr at 4 weeks of age and remained at that level throughout the entire period studied. The palmitic acid taken up by the lung was rapidly esterified $(58 \%$ esterification after $30 \mathrm{~min}$ of incubation and $85-90 \%$ at the end of $3 \mathrm{hr}$ of incubation). It can be seen from Figure 3 that an identical percentage of palmitic acid was esterified by the lung in rabbits of various ages. There were no age differences in the amount of palmitate incorporated into phospholipids $(60-70 \%)$ or in the biosynthesis of lecithin (50$60 \%$ of total phospholiids). Addition of choline $(10 \mathrm{mM})$ to the incubation medium did not affect the rate of palmitate incorporation into lung lipids at all ages studied.

\section{DISCUSSION}

The results of the present study show that 3 days before birth the rabbit lung is highly active metabolically. Although lung 


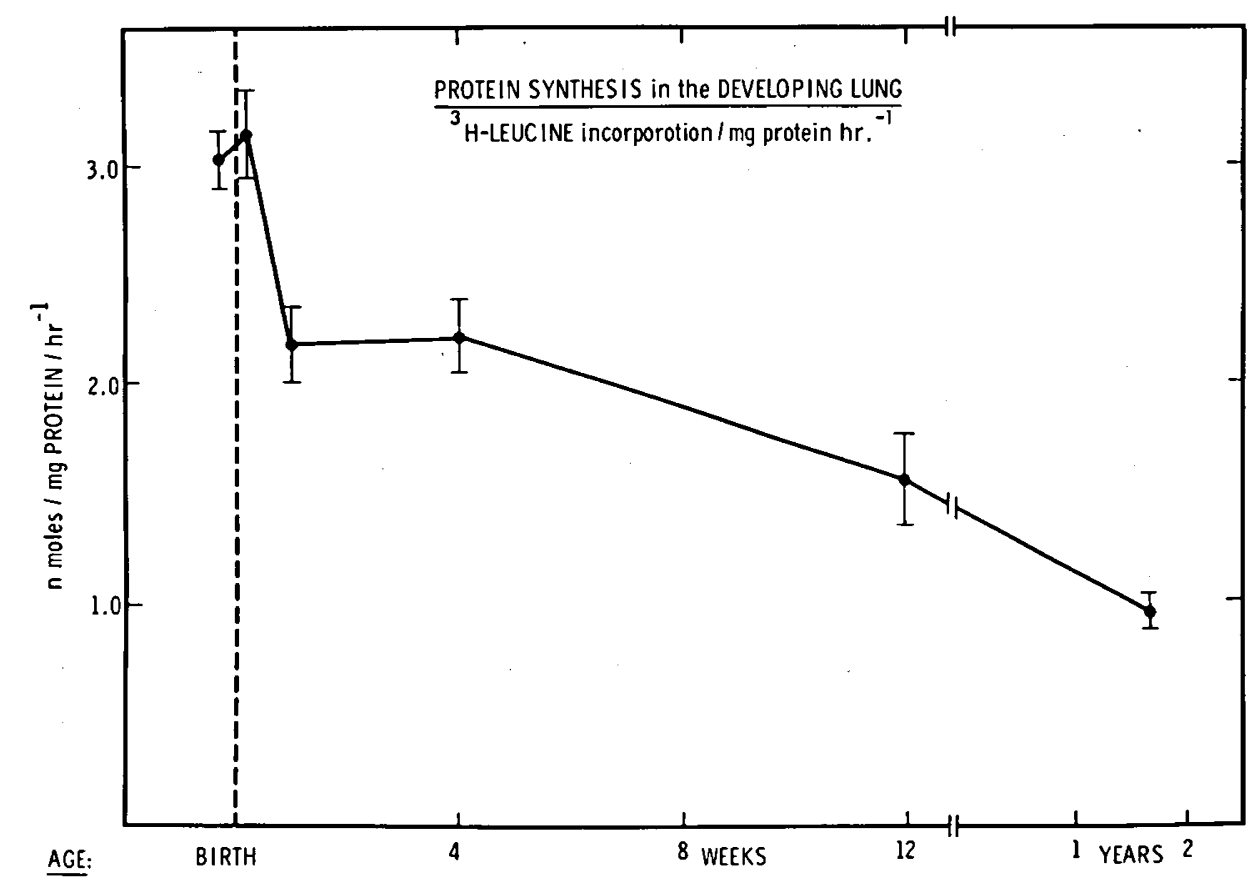

Fig. 1. Protein synthesis in the developing lung. Details of incubation and analytic procedures are given in Methods.

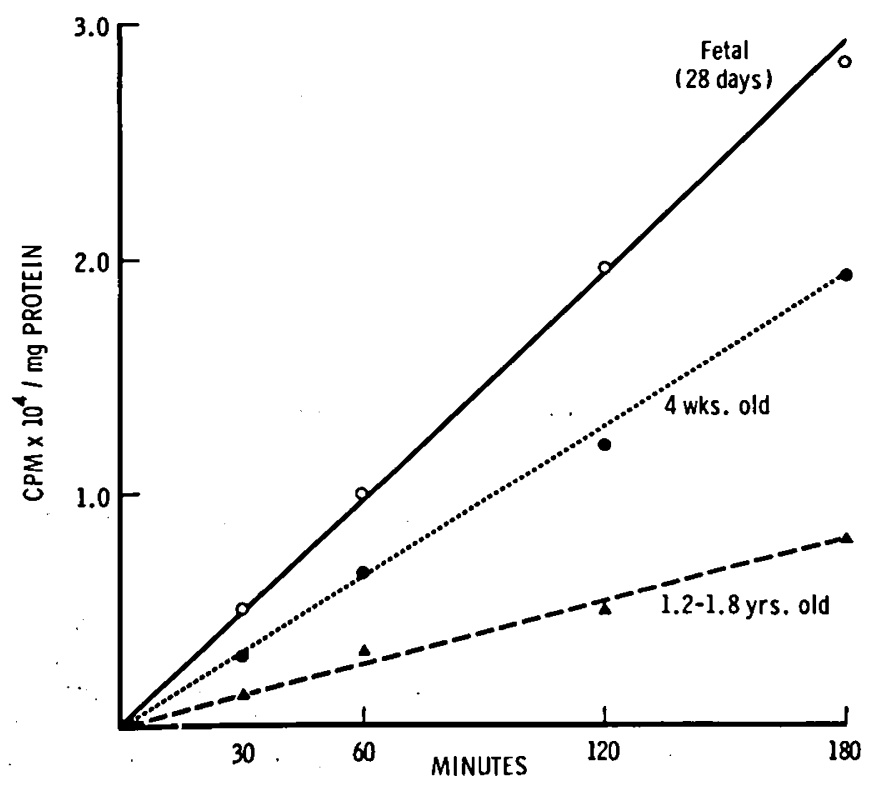

Fig. 2. Time course of $\left[{ }^{3} \mathrm{H}\right]$ leucine incorporation into lung protein. For details see Methods.

composition (Tables 1,2 , and 3 ) does not change markedly during the perinatal period (from 3 days before birth to 1 week after birth) there are marked changes in lung metabolism. Our data on the rapid decrease of lung weight relative to body weight during the last days of gestation and immediately after birth agree well with earlier observations (21) and show in addition that this ratio changes only little after 4 weeks of age (Table 1). The great similarity in lung composition 3 days before birth to that of lungs 1 and 7 days after birth seems to indicate that rabbit lungs have reached a considerable degree of maturity 3 days before birth. This assumption is supported by observations that after 28 days gestation, the fetal rabbit lung contains substantial amounts of surfactant (28) and, furthermore, that after this age the air spaces contain adequate surfactant concentrations (7). Lung dry weight, protein, DNA, and RNA concentration (Table 2) were almost constant during the perinatal period.

The decrease in lung DNA and protein concentration that accompanies accelerated lung maturation after corticosteroid administration (5) is probably not related to the maturation of the lung per se, but is mainly due to the growth-inhibiting effect of corticosteriods (19). There was a slight rise in lung lipid concentration throughout the period studied; however, there were no changes in lipid composition (Table 3 ). Phosphatidyl choline concentration remained relatively constant at 52-54\% of total phospholipids (Table 3 ). These results agree well with recently published observations (30). In contrast to the lipids in lung parenchyma, the phospholipids of lung wash have been shown to increase several-fold during the last 4 days of gestation (28), and especially after the onset of breathing $(13,20,28)$. This is probably related to more efficient surfactant secretion into the airways of fetal rabbits after 28 days of gestation (7).

There are marked differences in glucose metabolism between lungs of fetal rabbits and those of older rabbits. Glucose uptake and lactate production were higher in fetal lungs than in all other age groups. Our data of higher lactic acid production in fetal and neonatal rabbits agree well with a similar study in rats in which higher lactic acid production was found in slices of fetal lung when compared to adult lung (32). The amount of lactic acid produced in slices of adult rabbit lung (Table 5), is almost identical with that produced in lung slices of adult rats $(26,32,33)$.

Of special significance seems to be the fact that lipid biosynthesis from glucose is 3 times higher in fetal lungs and, furthermore, that a large part $(60 \%)$ of glucose carbon atoms channeled into lipid are incorporated into fatty acids; at all other ages glucose is chiefly a precursor of lipid glycerol and only a relatively small amount $(10-15 \%)$ is incorporated into glyceridefatty acids (10). Since glucose carbons are incorporated chiefly (75-80\%) into phospholipids, the 7- to 8-fold higher incorporation of glucose into fatty acids during the fetal period may have special significance in specific phospholipid synthesis, possibly surfactant.

Protein synthesis was highest in fetal and neonatal lungs, and decreased $30 \%$ during the first week after birth. There was a further gradual decrease during the entire period studied (Fig. 1). Our data are at variance with those of Bradley et al. (3), who reported a marked fall in protein synthesis during the last ten days before birth. We do not known whether this difference is due to the fact that we used leucine whereas Bradley used proline in the protein synthesis experiments, or to the fact that in our studies the incubation medium contained $75 \mathrm{mg} / 100 \mathrm{ml}$ 
Table 5. $D-\left[U-{ }^{14} C\right] G l u c o s e ~ m e t a b o l i s m^{1}$

\begin{tabular}{|c|c|c|c|c|c|}
\hline Age & Glucose uptake & $\begin{array}{l}\text { Lactate production, } \\
\mu \mathrm{mol} / 100 \mathrm{mg} / \mathrm{hr}^{2}\end{array}$ & Lipid synthesis & $\begin{array}{c}\text { Glycerol/ }{ }^{3} \text { fatty acid } \\
\text { ratio }\end{array}$ & $\mathrm{CO}_{2}^{4}$ production, \% \\
\hline Fetal (28 days) & $1.51 \pm 0.12$ & $2.3 \pm 0.48$ & $0.10 \pm 0.01$ & $1.54 \pm 0.16$ & $17.0 \pm 1.3$ \\
\hline 1 day & $1.20 \pm 0.18$ & $1.7 \pm 0.28$ & $0.026 \pm 0.004$ & $3.62 \pm 0.28$ & $14.0 \pm 2.0$ \\
\hline 7 days & $1.15 \pm 0.20$ & $1.2 \pm 0.16$ & $0.027 \pm 0.007$ & $6.38 \pm 0.80$ & $13.5 \pm 1.7$ \\
\hline 30 days & $0.98 \pm 0.15$ & $1.0 \pm 0.12$ & $0.033 \pm 0.006$ & $8.00 \pm 1.0$ & $14.8 \pm 1.9$ \\
\hline 90 days & $1.12 \pm 0.14$ & $1.1 \pm 0.25$ & $0.040 \pm 0.012$ & $7.70 \pm 0.85$ & $16.0 \pm 2.1$ \\
\hline $1.2-1.8$ years & $1.05 \pm 0.11$ & $0.96 \pm 0.10$ & $0.038 \pm 0.006$ & $7.00 \pm 0.60$ & $17.3 \pm 1.5$ \\
\hline
\end{tabular}

1 Results are mean $\pm \mathrm{SE}$. There were $6-12$ rabbits in each age group.

${ }^{2}$ Wet weight.

${ }^{3}$ Lung lipids were hydrolyzed to free glycerol and fatty acids and the amount of label in each fraction was measured; see Methods for details.

${ }^{4}$ Percentage of uptake.

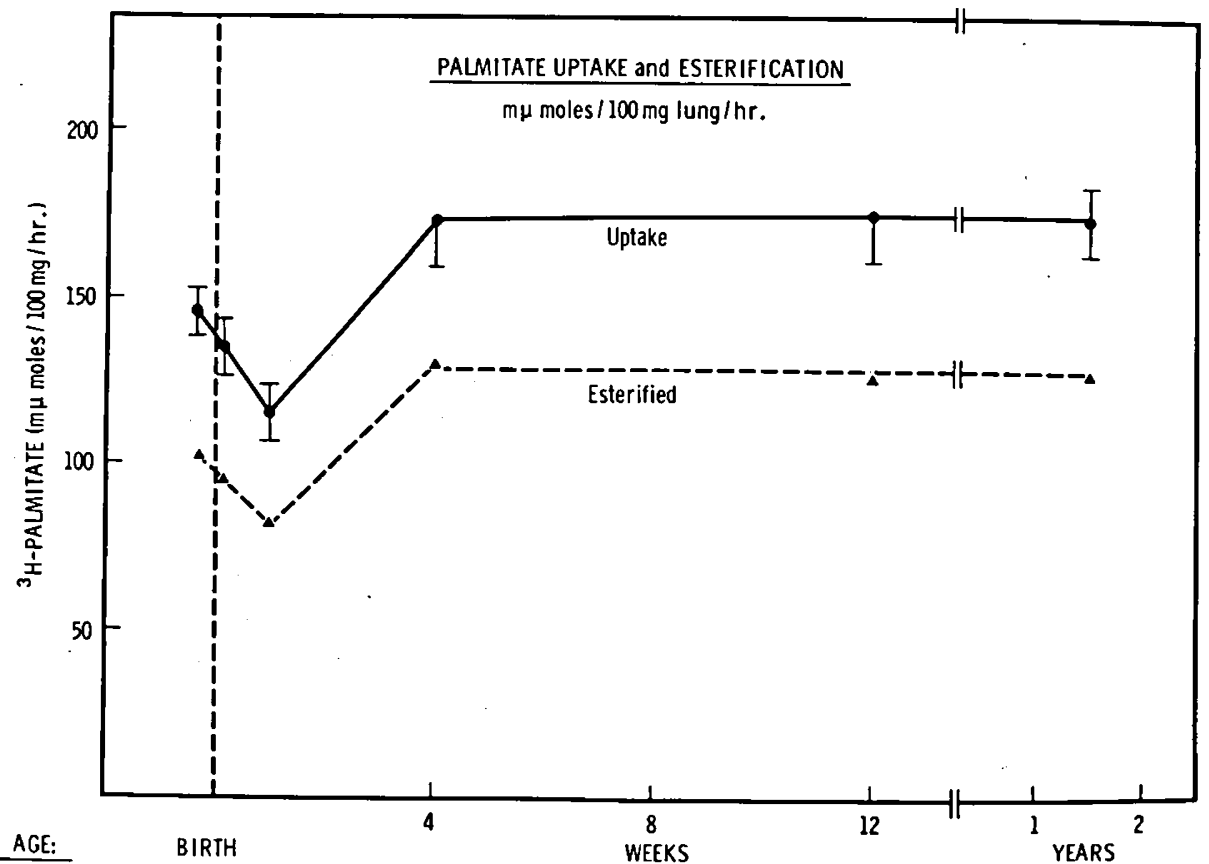

Fig. 3. Uptake and esterification of $\left[{ }^{3} \mathrm{H}\right]$ palmitic acid by lung slices. Of the palmitic acid taken up by the lung $85-90 \%$ was esterfied during $3 \mathrm{hr}$ of incubation. Of the palmitic acid $60-70 \%$ was incorporated into phospholipids.

glucose. Glucose has been shown to stimulate leucine incorporation into protein in lung slice preparations (25).

Whereas acetate incorporation into lung fatty acids increases 5-10 times during the first 2 weeks after birth and is very low in adult animals (6), our experiments show that incorporation of long chain fatty acids (palmitate) into lung lipids is almost constant throughout life (Fig. 3). Our data agree well with in vivo studies in fetal and newborn lambs in which it was shown that after injection of labeled palmitate, the specific activity of whole lung lecithin was similar in fetal and newborn lambs (12).

The present study shows that late fetal lung has a high metabolic activity that corresponds to the high synthetic demands of a rapidly growing and differentating organ.

\section{CONCLUSION}

Lung composition (dry weight, protein, DNA, RNA, neutral and phospholipid) was studied in late fetal, newborn, and developing rabbits and compared to that of adult and old (11.5 years) animals. Lung composition changed very little during the perinatal period ( 3 days before birth to 7 days after birth). After 30 days of age there was a slight decrease in DNA concentration and a concomittant rise in dry weight, protein, and lipid content of rabbit lungs. Lung metabolism, however, was markedly different at various developmental periods. Glucose uptake and lactate production was highest in fetal lungs; fatty acid synthesis from glucose was also highest at this age.
Leucine incorporation into protein was highest in fetal and neonatal lungs, and decreased $30 \%$ during the first week after birth. Incorporation of long chain fatty acids (palmitate) into lung lipids was almost constant throughout life. These observations show that during the perinatal period rabbit lung has a high metabolic activity necessary to meet the high synthetic demands of this rapidly growing and differentiating organ.

\section{REFERENCES AND NOTES}

1. Bartlett, C. R.: Phosphorus assay in column chromatography. J. Biol. Chem. 234: 466 (1959).

2. Borgstrom, B.: Investigation on lipid separation methods: Separation of cholesterol esters, glycerides, and free fatty acids. Acta Physiol. Scand., 25: 111 (1952).

3. Bradley, K. H., McConnell, S. D., and Crystal, R. G.: Lung collagen composition and synthesis: Characterization, and changes with age. J. Biol. Chem., 249: 2674 (1974).

4. Burton K.: A study of the conditions and mechanism of the diphenylamine reaction for the colorimetric estimation of deoxyribonucleic acid. Biochem. J., 62: 315 (1956)

5. Carson, S. H., Taeusch, H. W., Jr., and Avery, M. E.: Inhibition of lung cell division after hydrocrotisone injection into fetal rabbits. J. Appl. Physiol. 34: 660 (1973).

6. Chida, N., and Adams, F. H.: Incorporation of acetate into lecithin by lung slices from fetal and newborn lambs. J. Lipid Res, 8: 335 (1967).

7. Corbet, A. J. S., Flox, P., and Rudolph, A. J.: Reduced surface tension in lungs of fetal rabbits injected with pilocarpine. J. Appl. Physiol., 41: 7 (1976).

8. Darrah, H. K., and Hedley-Whyte, J. J.: Rapid incorporation of palmitate into lung: site and metabolic fate. J. Appl. Physiol., 34: 205 (1973).

9. Farrell, P. M., and Avery, M. E.: Hyaline membrane disease. Amer. Rev. Resp. Dis., 111: 657 (1975). 
10. Felts, J. M.: Biochemistry of the lung. Health Phys., 10: 973 (1964).

11. Folch, J., Lees, M., and Sloane Stanley, G. H.: A simple method for the isolation and purification of total lipids from animal tissues. J. Biol. Chem., 226: 497 (1957).

12. Fujiwara, T., and Adams, F. H.: Incorporation of labeled palmitate into "alveolar" and whole lung phospholipids of fetal and newborn lambs. Proc. Soc. Exp. Biol. Med., 128: 88 (1968).

13. Gluck, L., and Kulovich, M. V.: Fetal lung development: Current concepts. Pediat. Clin. N. Amer., 20: 367 (1973).

14. Gluck, L., Motoyama, E. K., Smith, H. L., and Kulovich, M. V.: The biochemical development of surface activity in mammalian lung. Pediat. Res., I, 237 (1967).

15. Glucostat for the enzymatic determination of glucose. In: The Worthington Manual, (Worthington Biochemical Corp., Freehold, NJ, 1972).

16. Hamosh, M., and Scow, R. O.: Lingual lipase and its role in the digestion of dietary lipid. J. Clin. Invest, 52: 88 (1973).

17. Hohorst, H. J. Lactate determination with lactic dehydrogenase and DPN. In H. U. Bergmeyer: Methods of Enzymatic Analysis, p. 266 (Academic Press, NY, 1965).

18. Horwitz, A. L., and Crystal, R. G. Content and synthesis of glycosaminoglycans in the developing lung. J. Clin. Invest., 56: 1312 (1975).

19. Howard, E. Effects of corticosterone and food restriction on growth and on DNA, RNA, and cholesterol contents of the brain and liver in infant mice. Neurochemistry, 12: 181 (1965).

20. Keidel, W. N., and Gluck, L.: Lipid biochemistry and biochemical development of the lung. In: E. M. Scarpelli: Pulmonary Physiology of the Fetus and Newborn Child, p. 96 (Lea \& Febiger, Philadelphia, 1975).

21. Kotas, R. V., Fletcher, B. D., Torday, J., and Avery, M. E.: Evidence for independent regulators of organ maturation in fetal rabbits. Pediatrics, 47: 57 (1971).

22. Levy; S. E., and Harvey, E.: The effect of tissue slicing on rat lung metabolism. J. Appl. Physiol., 37: 239 (1974).

23. Lowry, O. H., Rosebrough, N. J. Farr, A. L., and Randall, R. J.: Protein measurement with the Folin phenol reagent. J. Biol. Chem., 193: 265 (1951).

24. Massaro, D.: Alveolar cells: Incorporation of carbohydrate into protein and evidence for intracellular protein transport. J. Clin. Invest., 47: 336

0031-3998/78/1202-0095\$02.00/0

Copyright () 1978 International Pediatric Research Foundation, Inc.
(1968).

25. Massaro, D., Simon, M. R., and Steinkamp, H.: Metabolic factors affecting protein synthesis by lung in vitro. J. Appl. Physiol., 30: 1 (1971).

26. O'Neil, J. J., and Tierney, D. F.: Rat lung metabolism: glucose utilization by isolated perfused lungs and tissue slices. Amer. J. Physiol., 226: 867 (1974).

27. Rapport, M. M., and Alonzo, M.: Photometric determination of fatty acid ester groups in phospholipids. J. Biol. Chem., 217: 193 (1959).

28. Rooney, S. A., Wai-Lee, T. S., Gobran, L., and Motoyama, E. K.: Phospholipid content, composition, and biosynthesis during fetal lung development in the rabbit. Biochim. Biophys. Acta, $431: 447$ (1976).

29. Schneider, W. C.: Determination of nucleic acids in tissues by pentose analysis. Methods Enzymol, 3: 680 (1957).

30. Soodsma, J. F., Mims, L. C., and Harlow, R. D.: The analysis of the molecular species of fetal rabbit lung phosphatidyl choline by consecutive chromatographic techniques. Biochim. Biophys. Acta, 424: 159 (1976).

31. Umbreit, W. W., Burris, R. H., and Stauffer, J.: Manometric Techniques, p. 149 (Burgess Publishing Co., Minneapolis, 1957).

32. Yeager, H., Jr., and Hicks, P. S.: Glucose metabolism in lung slices of late fetal, newborn and adult rats. Proc. Soc. Exp. Biol. Med., 141: 1 (1972).

33. Yeager, H., Jr., and Massaro, D. Glucose metabolism and glycoprotein synthesis by lung slices. J. Appl. Physiol., 32: 477 (1972).

34. Zeligs, B. J., Zeligs, J. D., Nerurkar, L. S., and Bellanti, J. A.: Maturation of the alveolar macrophage in the rabit during development. I. Perinatal influx into aiveoli and ultrastructural differentiation. Pediat. Res., 11: 197 1977.

35. The authors thank Linda Cooper, Ruth Avigan, and Renee Hawkins for excellent technical assistance, and Teresa Koncick for secretarial help. We wish to thank Drs. J. A. Bellanti, L. Nerurkar, and Ms. B. Zeligs for providing rabbit lungs.

36. This research was supported by grants from the National Institute of Health HL 19056 and the Council for Tobacco Research-USA, Inc.

37. Requests for reprints should be addressed to: M. Hamosh, Ph.D., Department of Physiology and Biophysics, Georgetown University School of Medicine, Washington, DC 20007 (USA).

38. Received for publication March $15,1977$.

39. Accepted for publication May $6,1977$.

Pediat. Res. 12: 100-104 (1978)

$\begin{array}{ll}\text { Adenylate cyclase } & \text { exocrine glands } \\ \text { carbachol } & \text { isoproterenol } \\ \text { cyclic AMP } & \text { parotid gland } \\ \text { epinephrine } & \text { secretory function, development }\end{array}$

\title{
Development of Secretory Function in Rat Parotid Gland
}

\author{
RICHARD J. GRAND, (24) AND MARIA I. SCHAY \\ Department of Pediatrics, Harvard Medical School, and the Department of Medicine (Division of \\ Gastroenterology), the Children's Hospital Medical Center, Boston, Massachusetts, USA
}

\section{Summary}

Because very little is known regarding the control of enzyme secretion in developing parotid glands, the effects of various secretagogues on cyclic AMP levels and amylase release were studied in rats at various times after birth. In parotid fragments or slices incubated with isoproterenol or epinephrine $(40 \mu \mathrm{M})$ in vitro, neither cyclic AMP elevation nor amylase release was achieved at 8 days postnatally. In in vivo studies, secretion of amylase at this age was also refractory to stimulation with these hormones or carbamylcholine. In animals older than 15 days, highly significant rise in cyclic AMP content occurred 5 min after exposure of the glands to the catecholamines in vitro, and the magnitude of this elevation was incremental with age. Thus, in 15-day-old animals adrenergic stimulation produced a 2 -fold rise in cyclic AMP levels (from $9.3 \pm 1.0 \mathrm{pmol} / \mathrm{mg}$ protein to $20.9 \pm 4.7$, mean $\pm \mathrm{SE}$ ); at 25 days the increase was 7-8 times the basal value (from $2.7 \pm 0.3$ to $21.3 \pm 3.9$ ); and at 8 weeks the rise was 8-fold with epinephrine (from $3.2 \pm 0.3$ to $24.4 \pm 7.5$ ) and 12-fold after isoproterenol (from $3.2 \pm 0.3$ to $39.2 \pm 9.2)$. At these ages, adrenergic stimulation led to a 2 - to 3-fold increase in amylase secretion compared to unstimulated control levels. When isoproterenol (16 $\mu \mathrm{g} / \mathrm{g}$ body weight) was injected intraperitoneally in intact animals 15 days of age or older cyclic AMP levels 5 min later were increased 2-3 times in 15- and 25-day-old animals (from $13.9 \pm 4.4$ to $49.3 \pm 3.9$ and $31.3 \pm 4.0$, respectively) and $>100$-fold in mature animals $(1211 \pm 437)$. Greater than $40 \%$ of the stored amylase was released from the glands in $30 \mathrm{~min}$, a quantity comparable to that found in vitro. The data demonstrate that the responsiveness of the parotid gland to catecholamines is age dependent, and that development of secretory function precedes full morphologic and biochemical development.

\section{Speculation}

The identification of a stage in exocrine development when the immature parotid glands are refractory to secretory stimuli represents an important model for the study of stimulus-secretion coupling. The acquisition of mature secretory function may depend upon the relationship between the number of cell surface hormone receptors and acinar maturation. 